\title{
A Theory of Impact Bonds as an Alternative to Pigouvian Tax and Public Provision: Application for Climate Change
}

\author{
Nathan Witkin \\ Outside Innovation Institute
}

Instead of addressing externalities with taxes or subsidies, this paper proposes a process in which the government estimates the overall cost of an externality and then offers a lesser amount to the private enterprise that resolves the externality. This paper offers a theoretical framework for resolving externalities, applies this as a theory of social impact bonds, and uses private industry solutions to climate change as an example of how this process would work. Government could therefore identify the social price of public problems, offer a lesser amount to fix them, and then allow investors to organize markets around potential solutions.

Keywords: Theoretical Economics, Externalities, Impact Bonds, Pay-For-Success, Climate Change

\section{INTRODUCTION}

This paper offers a promising process for delivering public goods, proposes a unique economic approach to externalities to fit this process, and applies these ideas as a solution to climate change. Under this new approach to governance, government would offer large, one-time payments for public goods under open pay-for-success arrangements and then allow investors to organize markets to produce those particular public goods. In contrast to standard economic theory that addresses externalities with taxes and subsidies on each transaction, the proposed approach involves a lump-sum payment that is offered to whichever private entity creates a solution to the externality that meets the criteria defined by the government body.

For example, carbon emissions are expected to create an external cost to society in the trillions of dollars. Even if priced perfectly, a per-unit tax on carbon emissions will therefore transfer trillions of dollars through government processes, slowing the economy and affecting the poorest segments of society. The government could subsidize carbon sequestration on a per unit basis or fund massive investment into a Green New Deal; however, both would be extremely expensive. Instead, the government could make an open promise to pay a billion-dollar prize to the firm that lowers the cost of carbon sequestration to meet defined metrics. Carbon sequestration is a public good that is underprovided by the private market but small companies have made significant strides in bringing the cost of sequestration close to the external cost of emitting carbon. Given that this solution could save trillions of dollars, it should come as a pleasant surprise that the amount of private investment that it took to achieve these gains was only in the tens of millions of dollars. If the government offered a ten-billion-dollar prize for a climate change solution, experience from social impact bond projects indicates that investors will 
organize a market around this solution. This process would therefore harness the creativity and flexibility of private industry to complement the power of government in identifying and funding public goods.

To summarize, this paper proposes an approach to externalities that harmonizes the strengths of the public sector and private sector. Instead of taxing the problem or subsidizing the solution on a per-unit basis, a government could project the long-term costs of the problem and offer a fraction of that cost to any private entity that delivers a solution. This suggests a theoretical framework around "impact bonds" in which a government body identifies a public good and the price society would be willing to pay for it and then allows the private market to innovate and optimize. The following analysis begins with a description and critique of current economic theory supporting per-unit government interventions over externalities. It then proposes a social pricing model for externalities based on their cumulative rather than per-unit cost. This theoretical approach supports the process central to this paper in which government sets the price of the public good, allowing the private sector to find and support organizations with potential to meet the metrics defined in the government's open pay-for-success contract. This process is supported by and offered as a theoretical framework around social impact bonds. All of these ideas are then illustrated with a proposed application to externalities stemming from carbon emissions. The paper concludes by suggesting theoretical implications for the overall function of government.

\section{CURRENT THINKING ON EXTERNALITIES: REDISTRIBUTION RATHER THAN SOLUTION}

The approach to externalities under public policy informed by classical economic theory involves taxing social damage or subsidizing social benefits on a per-unit basis. This paper will present another approach that could be more efficient and effective in many circumstances.

Under Arthur Pigou's analysis, an externality occurs when the private impact of selling a unit of a good is different from the social impact (Caldari \& Masini 2011). These situations lead to the overproduction of goods that cause a negative externality and an underproduction of goods that cause a positive externality (Williams, Swenson, and Lease, 2001). Because prices do not maximize social surplus in these situations, Pigou argued that the government was justified in intervening by taxing the negative externalities and subsidizing the positive externalities in order to align social value with prices facing individuals in the market (Caldari \& Masini 2011).

A Pigouvian intervention that is set equal to the marginal cost or benefit of an externality theoretically removes the distortion of the externality and results in socially optimal consumption (Gruber, 2016, p. 125-139) (see Figures 1 and 2).

FIGURE 1

\section{PIGOUVIAN TAX}

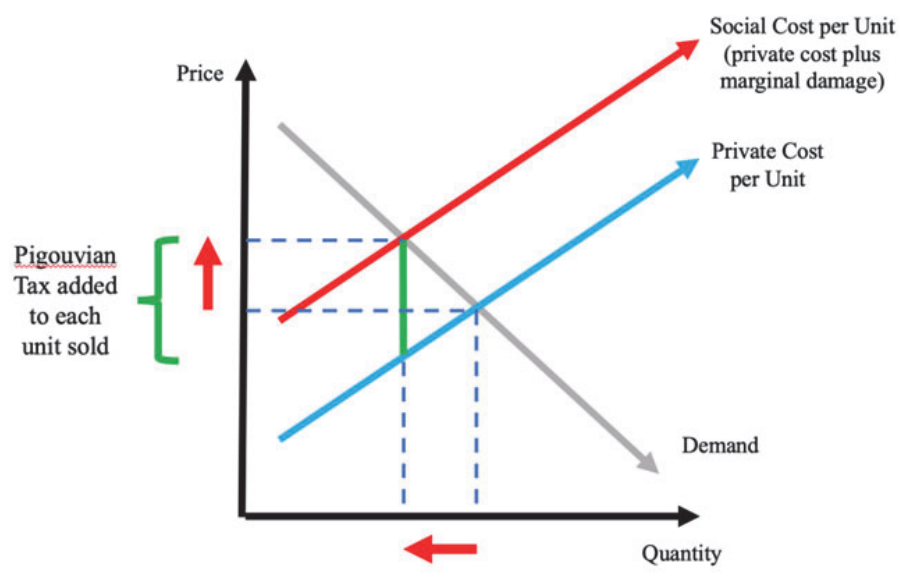


FIGURE 2

\section{PIGOUVIAN SUBSIDY}

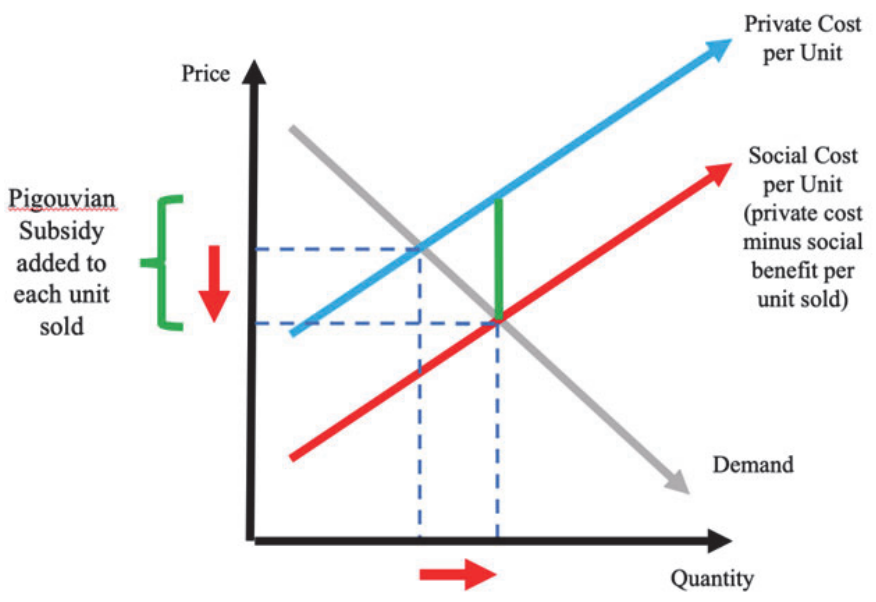

However, unlike the goal of the policy intervention proposed in this paper, a Pigouvian intervention aims to redistribute resources rather than fix the externality. The goal of a Pigouvian tax is to collect, from participants to a transaction, the amount of money demanded by people who are not involved in the transaction to accept the externality and then compensate them that amount (Baffi, 2013, p. 47). The goal of a Pigouvian subsidy is to collect, from taxpayers, the amount of benefit received by people who are not involved in a transaction and then subsidize the transactions by that amount. Though the point of Pigouvian analysis is not to set a price for resolving the externality, this does not mean that doing so is impossible or futile.

It is important to remember that the size of Pigouvian interventions do not reflect the cost of fixing the externality. Fixing the externality would involve finding and funding a process to reduce the social cost of a negative externality (making the problem-causing market process less harmful) or supporting the development of a positive externality (making the benefit-causing market process less costly or more effective). Externalities and fixes are likely not perfectly matched-many externalities may not have a solution, and some may have multiple feasible solutions. For example, carbon capture technology is one possible solution to the externalities of carbon emissions, but is not necessarily the only one.

When the externality damage is less than the cost of the solution to the externality, the optimal approach is to allow the externality to exist with Pigouvian interventions redistributing funds to maximize social welfare. Meanwhile, when the cost of the solution is less than the overall externality cost, the optimal approach is to fund the appropriate measures to fix or resolve the externality. Determining which of these two approaches is more efficient requires a comparison of the total cost of resolving the externality to the total cost of allowing the externality to continue.

Here, this paper draws a distinction from Pigouvian analysis. Because the Pigouvian approach focuses on the per-unit cost/benefit of the externality, estimating the total value of resolving an externality requires a different method of measuring its impact. The expense required in resolving an externality should be weighed against the externality's projected long-term costs if left unresolved, and not its perunit cost in current transactions. The following sections therefore offer a critique of the Pigouvian approach to measuring externalities, a description of externality fixes, and then a new approach that attempts to measure the overall impact of externalities.

\section{PROBLEMS WITH PER-UNIT MARKET INTERVENTIONS}

The unintended problems with Pigouvian interventions center on their nature as a per-unit addition or subtraction, administered by a government body, to market transactions. Even when it is applied ideally, a 
Pigouvian tax causes the market in the externality-producing good to slow down by design (Tideman \& Plassmann, 2010). Also, a Pigouvian subsidy involves the incredible expense of the government paying an extra amount for each unit sold (Sterner, 2002, p. 103), even on units that would have been sold without the subsidy (Metcalf, 2009, p. 524). Beyond these intended problems, Pigouvian interventions suffer from a number of problems not inherent to their design.

First, these interventions are generally inaccurate. Pigouvian taxes and subsidies are likely to be suboptimal (too much or too little) because government officials do not have perfect information about the per unit social cost or benefit of each unit of a good (Madjd-Sadjadi, 2016: 147; Masur \& Posner, 2015: 138). Furthermore, the marginal social cost or benefit of an activity depends on idiosyncrasies of the individual or firm conducting it (Masur \& Posner, 2015: 138). Also, even if the per-unit cost was accurate when applied, Coase argued that setting a tax equal to the size of the externality will create repercussions in behavior rendering the tax unequal to the negative social welfare caused by the transactions (Schlag, 1989). Also, because social cost is often difficult to quantify, Pigouvian arguments can disguise government subsidies awarded for political reasons (Acemoglu \& Robinson, 2001; Fredriksson, 1997).

Second, the effectiveness of a Pigouvian intervention is diminished by the transaction costs of collecting and distributing this per-unit cost. One reason for this is that a Pigouvian tax transfers funds to the government rather than to the uncompensated victims of the transaction, and the government must then identify and compensate them without political distortions (Madjd-Sadjadi, 2016: 149). This per-unit government involvement therefore requires great efficiency, wisdom, and benevolence on the part of bureaucrats to achieve overall efficiency.

Third, Pigouvian taxes have political flaws. The more-obvious aspect of this problem is that a Pigouvian tax concentrates costs to a specific constituency and then distributes benefits across society. Because it has salient costs on certain groups and dispersed benefits, Pigouvian taxes are among the most difficult policies to legislate (Wilson \& Dilulio Jr., 1995, p. 478). The less-obvious aspect of the political problems of Pigouvian taxes is that it involves a per unit price on things we as a society are uncomfortable with "pricing," such as human lives in healthcare and permission to pollute the environment (Masur \& Posner, 2015: 99, 139-143). Instead, people prefer that social costs be aggregated and paid for by society collectively - this implies a vertical aggregation of cost curves, whereas charging people a per-unit cost to conduct social harm involves a horizontal aggregation of price/quantity cost curves (discussed later).

The problems with per-unit market interventions generally support fixing or reducing the externality, when doing so is possible. The following section describes approaches to resolving externalities, and then the subsequent section presents a framework for measuring the value of these solutions.

\section{THE SOLUTION TO AN EXTERNALITY: LESSEN THE NEGATIVE OR ENHANCE THE POSITIVE}

Solutions to externalities are the goods or services that reduce the harm of negative externalities or support the development of positive externalities in market transactions. These solutions typically take the form of innovations that have beneficial spillovers (Bretschger, 2005, p. 153). When a solution to an externality has a lower social cost than the continuing effects of the externality, then the solution is efficient. Noting that externalities which cannot be efficiently reduced should undergo Pigouvian redistribution, the remainder of the paper will discuss strategies, implications, and possibilities for reducing or resolving externalities.

A solution to an externality matches a negative externality (i.e., a problem) to a positive externality (i.e., a solution). Overproducing costs not included in the price and underproducing benefits not included in the price can be alternative conceptions of the same externality. This is why the presence of a negative externality indicates the absence of a positive externality, and vice versa (Steinacker, 2006, p. 459). When the two are perfectly matched, there is no externality in the free market. For example, if manure from a ranch is a negative externality to the village but a positive externality to farmers who can use it as 
fertilizer, then it is internalized into the market when sold by the rancher to the farmer. Because they cannot always be perfectly matched in this way, reducing an externality often involves lessening the cost of a negative externality or enhancing the benefit of a positive externality.

Perfectly effective efforts to reduce a negative externality and enhance the corresponding positive externality are equivalent in terms of societal impact. Therefore, inputs that reduce the pollutant emitted in a production process are as effective as technologies that capture the same amount of pollutant as it is emitted. This is analogous to, but different from, the way taxes and subsidies produce the same direct effects on the externality when set equal to the marginal difference between social and private costs (Nault, 1996, p. 308; Heres, et al., 2017). The difference is that, while taxes and subsidies occur with each unit transacted, a solution to an externality involves an innovation which reduces the harm or enhances the benefit of market processes.

Though the social damage of releasing a pollutant is equivalent to the social benefit of sequestering that pollutant, this does not mean that the cost of each process is the same. Innovations that reduce the harm of negative externalities may be more or less cost-effective that innovations that enhance the benefit of corresponding positive externalities. While most externalities appear to be easier to resolve by reducing the negative externality, there may be types of societal problems for which it is more efficient to enhance the positive externality. For example, when addressing a highly transmittable contagion that causes disease in a small subset of a larger population, it may be more cost-effective to improve disease treatment than to institute behavioral restrictions on the entire society to prevent its spread. Also, this differential effectiveness between reducing harm and enhancing benefits may be why reduction of sulfur dioxide emissions was successfully legislated while efforts to reduce carbon dioxide emissions have floundered (Chan, et al., 2012) — producers were able to find substitutes for sulfur-emitting energy sources but were not able to do so for carbon-emitting ones.

The key implication from this section is that-unlike a Pigouvian intervention in which the cost imposed to actors is set equal to the damage from the externality - the cost of resolving an externality is not related to the damage of the externality itself. Whether resolving the externality is worth the expense involves comparing the cost of the solution to the cost of allowing the externality to continue unresolved. As the next section explores, reducing a negative externality and enhancing a positive externality are both public goods and should be priced differently from private goods.

\section{PRICING THE SOLUTION TO AN EXTERNALITY: CUMULATIVE AGGREGATION}

If the goal is resolving the externality, the deficiency with the Pigouvian approach is not in charging a price for externalities but in measuring that price as a per-unit tax or subsidy on transactions. When considering the cost-effectiveness of fixing an externality, the cost of that externality should be aggregated cumulatively to estimate its overall impact on society. This would allow society as a whole to decide how much to pay for solutions to public problems.

Reducing a negative externality or enhancing a positive externality applies a public goods framework because all potential victims of the externality benefit from its resolution in a way that is non-rivalrous and non-excludable (Ostrom, 2012, p. 354; VanDoren, 1989, p. 328; Miller, 2006). This distinction is important because demand for public goods are aggregated differently from private goods in public finance theory. Private goods are available to individuals in varying amounts, so decisions across the market are based on everyone paying the same price (Musgrave, 1956). Because price is plotted on the vertical axis and individual demand curves are aggregated together based on a fixed price, the market demand curve indicating overall quantity demanded of private goods is aggregated horizontally (to keep price fixed across quantities). Meanwhile, public goods are available to all once provided and therefore are consumed "in equal amounts by all" (Musgrave, 1956, p. 334). This means that aggregating a market demand curve for public goods is based on equal quantity rather than equal price for individuals and must be done vertically (to keep quantity fixed across prices) (Bowen, 1978, p. 176-78). As a result, judging the value to society of the solution to an externality involves adding each member of society's willingness to pay for that solution. 
That societal willingness to pay for the solution to an externality must be compared to the societal cost of not resolving it. This would require aggregating the cost of the externality over transactions and over time. Even under an optimal Pigouvian intervention, externalities still occur and would accumulate in the bigger picture (Johnson, 1995). As a result, each unit of damage imposed by a negative externality or benefit foregone by a positive externality would be added together to produce the societal value - the projected price - of the solution. For example, if a negative externality (such as climate change) were projected to cost $\$ 10$ trillion over 30 years, then the corresponding positive externality (for example, a technology that sequesters atmospheric carbon for storage or fuel) would be worth up to $\$ 10$ trillion over the same period.

Applying policy to externalities at the societal level would require a different measurement of externalities. Under current economic theory, the cost from a negative externality is marginal damage ("MD"), measured as the difference between the marginal cost of a transaction to society (social marginal cost or "SMC") and the marginal cost to participants in the transaction (private marginal cost or "PMC") (see Figure 3). The difference between the two graphs in Figures 3 and 4 is that Figure 3 illustrates the difference between SMC and PMC (the marginal damage) for each unit of the quantity bought/sold while Figure 4 illustrates the overall cost of the externality that has accumulated with each additional transaction. In other words, Figure 3 is a traditional supply-demand curve indicating the marginal damage individually occurring in each transaction (Pass, Lowes, and Davies, 2005), while Figure 4 indicates the total societal cost of the externality that has accumulated across transactions. Because a Pigouvian intervention occurs at each transaction, the important measure is the marginal damage from one transaction, illustrated in Figure 3 and in Equation (1).

$M D=S M C-P M C$

This measure of the marginal damage of an externality does not represent the total societal cost of the externality-producing process to be compared to the aggregation of societal demand for the solution for two reasons. First, the marginal damage is measured over one single transaction and is not the combined effects of all of the transactions occurring together. The overall cost of the externality summed across all transactions, $i$, is quantified in Equation (2) and indicated in the shaded areas of Figures 3 and 4. However, this only indicates the size of the externality occurring across simultaneous transactions at one time period (Johnson, 1995).

$M D_{i}=\sum_{i=1}^{I} S M C_{i}-P M C_{i}$

Second, the reason that marginal damage summed across transactions does not account for total societal costs of an externality is that these costs also accumulate over time. To measure the complete cost of the externality to society, we would need to measure marginal damage from all individual transactions occurring at one time, $i$, and also occurring across periods of time, $t$. This cumulative cost of an externality is quantified in Equation (3) and illustrated in the striped area of Figure 4.

$M D_{i t}=\sum_{t=1}^{T} \sum_{i=1}^{I}\left(S M C_{i}-P M C_{i}\right)_{t}$

144 Journal of Applied Business and Economics Vol. 21(5) 2019 


\section{FIGURE 3 \\ PER-UNIT COST OF EXTERNALITY}



FIGURE 4

CUMULATIVE COST OF EXTERNALITY

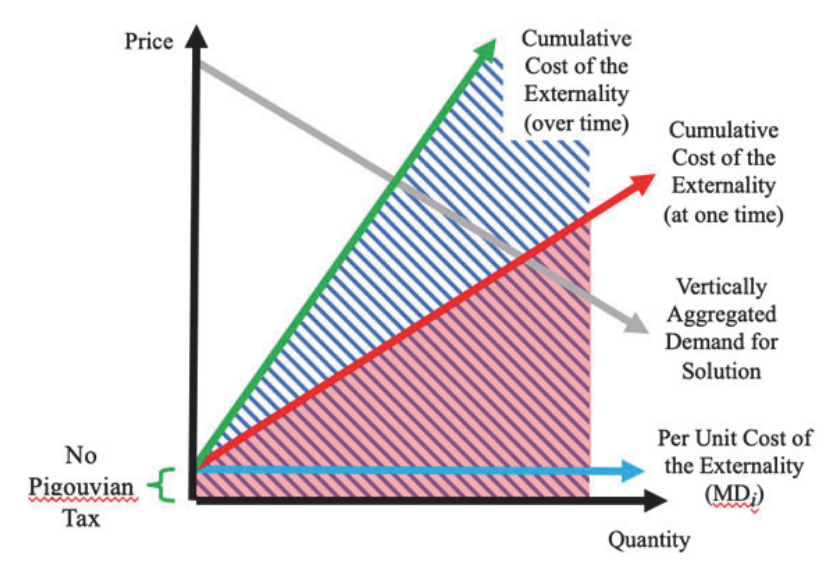

Figure 3 indicates that, when the cost of a transaction to its participants is lower than the cost of that transaction to society, then a lack of Pigouvian intervention leaves victims of the externality without the compensation they would have demanded to permit the externality to occur. Figure 4 illustrates thatunless a Pigouvian tax funds a resolution to the externality - the marginal damage caused by a negative externality from each unit transacted will accumulate over all transactions and across a defined time period into a larger cost for society.

Measuring the cost of externalities from a societal level addresses the three problems raised with perunit government intervention. First, an externality priced at a societal level would be experienced as more accurate because errors in measurement would be spread across society and individual feedback effects would not occur. Because public goods are not objectively measurable at the individual level (Paton \& Bryant, 2012, p. 96), they are "purchased" in a deliberative political process rather than a market transaction negotiated at the individual level (Spash, 2007). Second, pricing public goods at the societal level is cheaper when organizational costs for structuring economies of scale are less than transaction costs for overseeing markets (Cheng \& Zhang, 2006). Third, pricing externalities at the societal level should reduce political obstacles to imposing costs by spreading and abstracting the pricing process. If society was willing to pay for healthcare and environmental quality on a per-unit basis, economists would not have spent as much effort building processes to measure social prices for them (Richardson, et al., 2014; Orchard-Webb, et al., 2016). 
As implied in the previous section, the aggregated societal willingness to pay for a solution to the externality is not linked to the long-term cost of the externality under currently-available policy tools. This is why the cumulative cost of the externality in Figure 4 continues past the vertically aggregated demand of society for a solution to the externality. To fill the need for such a policymaking tool, this paper proposes a method for identifying and funding solutions to externalities that are within society's willingness to pay through governmental processes.

\section{A BETTER APPROACH: ENCOURAGING THE MARKET TO RESOLVE AGGREGATED EXTERNALITIES}

After economists estimate the overall cost of an externality in the above process, the policymakers are tasked with finding a solution to the externality that costs less. Because reducing costs or enhancing benefits of the market process requires innovation within the market, the best solution to an externality will likely come from within the private sector. And because lawmakers are not sure what exactly to request of citizens and will require greater effort from certain citizens than others, offering incentives should be the most effective approach (De Geest \& Dari-Mattiacci, 2013).

Based on the above analysis, I would suggest that governments seeking to resolve an externality set an overall price on it and allow investors to organize a market around promising solutions. This process would set government in the role of evaluating a societal cost and raising public funds for resolving it while private industry would take the role of attempting to meet the demand identified by government.

Rather than taxing or subsidizing the externality, the government could estimate the long-term, cumulative cost or value of the externality and use that information to set the price that it would be willing to pay for its solution. This means estimating the cumulative societal cost of a negative externality or the cumulative societal value of a positive externality and then offering a lesser amount to any private individual or firm that produces the solution to the problem.

With the government offering a large prize for the creation of a specific public good, I hypothesize that a market would form around the solution. In other words, investors would identify and support promising solutions, mobilizing the private market's strengths in disruptive innovation and managing risk in the face of uncertainty. Meanwhile, this approach also leverages the strengths of government in identifying externalities and in mobilizing resources from citizens to fund public goods.

Using the projected cumulative cost of an externality as the price society pays without a solution (Figure 4), a government can apply deliberative democratic processes to aggregate demand to determine how much society is willing to pay. Under optimal conditions, however, government as aggregator of social costs and demand will not always reach efficient solutions (Agiobenebo, 2006). Beyond channeling the collective will of society in resolving externalities, this proposed approach may also produce efficient outcomes. Under Pigouvian analysis, market transactions that would not occur if the cost of the externality was added to the price (those beyond the optimal quantity of transactions) are inefficient. The key to identifying this inefficiency is finding this optimal point past which transactions would not occur (Nye, 2008). The difference between what consumers would have been willing to pay (the demand curve) and the social cost of these transactions past this optimal quantity is deadweight loss, a measure of overall inefficiency (see Figure 5). Therefore, if the price offered by the government is less than the deadweight loss to society from the externality-producing activity, it would also be an efficient use of government funds.

We can therefore combine Pigou's analysis of externalities with the conception of government as a process for pricing societal costs and public demand to produce an overall efficient solution. As mentioned above, transactions are inefficient when they occur beyond the point where people are willing to pay for the extra cost of the externality. For these transactions, an accumulation of social cost theoretically does not occur because people pay an extra amount in the form of taxes, and government uses these taxes to provide the corresponding positive externality. From the perspective of cumulative rather than per-unit societal costs, however, social costs begin to accumulate past the point in which the government has collected taxes and provided public goods but problems persist. 
The limit of the willingness of society to levy taxes for social goods indicates the point where demand for government provision of those goods (indicating governmental effectiveness) reaches zero. Social problems that persist past this point accumulate uncompensated societal costs. A per-unit perspective on externalities defines inefficiency as transactions that occur but would not have occurred if the participants were required to pay for or internalize the cost of the externality (Gruber, 2016). From a cumulative societal cost perspective, inefficiency occurs when externality-producing transactions continue past the point at which society is willing to pay for government provision of the solution (see Figure 6).

\section{FIGURE 5 \\ INEFFICIENCY UNDER PIGOUVIAN ANALYSIS}



FIGURE 6

RESOLVABLE INEFFICIENCY UNDER CUMULATIVE SOCIETAL COST ANALYSIS

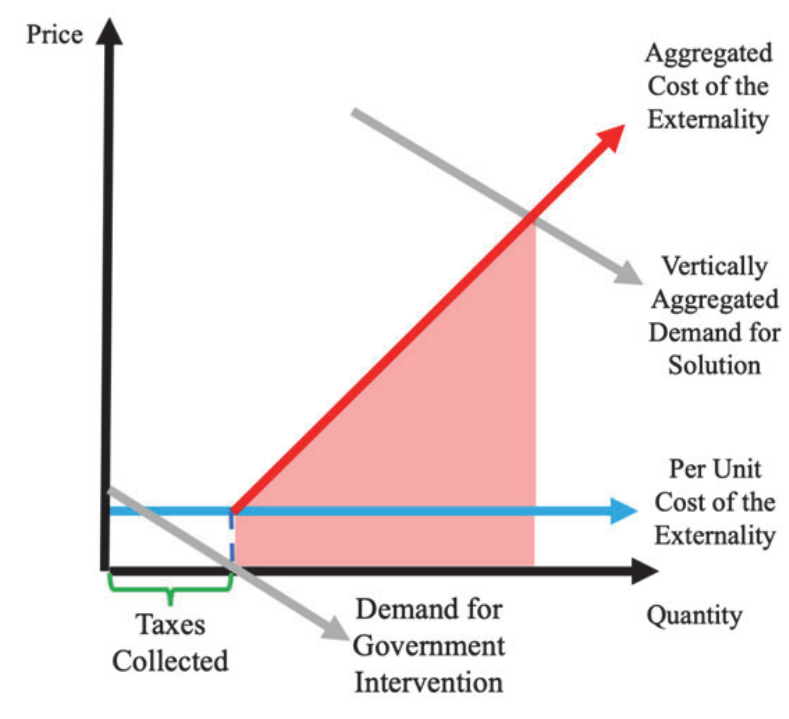

Journal of Applied Business and Economics Vol. 21(5) 2019147 
When individual demand curves for public goods aggregate above this point, then society has a willingness to pay for the solution to the externality that exceeds its willingness to resolve it through taxes and government provision of public goods. This means that the shaded area in Figure 6 indicates inefficiency that society would collectively be in favor of remedying but is not willing to do so by taxation and government provision.

This framework proposes that there could be a gap between the demand for traditional government interventions funded by taxation and the aggregated demand or society's willingness to pay for a solution to public problems. To fill this gap, government could set prices on a series of deliverables that reduce the problem, allowing investors to gather markets around solutions. Unlike subsidies, efforts to provide the public good will only be compensated if they are successful. And unlike government provision of public goods, the solutions are generated by the more flexible and innovative private sector. This process is very similar to the core idea behind social impact bonds.

\section{SOCIAL IMPACT BONDS: GOVERNMENTS PRICE THE PROBLEM, MARKETS PRODUCE SOLUTIONS}

The process for producing public goods against externalities proposed in this paper is analogous to "impact bonds" as a process in which government defines the price society would pay for a public good and investors seeking to earn this price find and fund promising solution. Analogies could also be drawn to $R \& D$ prizes or inducement prizes as incentives offered by the government for innovations from the private sector ( $\mathrm{Fu}$, et al., 2012). However, unlike impact bonds, R\&D prizes are intended to be an incentive but not the entire funding process for privately delivered public services. For example, the largest recorded inducement prize is $\$ 25$ million offered for commercially viable carbon capture technology, yet this is admittedly not enough to motivate sufficient investment to create this industry (Adler, 2011). Impact bonds for funding public goods have recently developed, beginning with social impact bonds.

Social impact bonds ("SIBs") are both an umbrella term for a new approach to public service provision and a part of this system (Rangan and Chase, 2015). The term "social impact bond" is misleading for two reasons: first, it is not a bond (Gilbert, 2011), and second, the term appears to be a synecdoche, in which part of a larger process is used to represent the entire process (Iovan, et al., 2018). Before explaining the implications of social impact bonds for the approach to externalities presented above, it is important to briefly analyze the phenomenon of social impact bonds.

The definition of social impact bond is often presented as synonymous with the pay-for-success ("PFS") approach to government services (Temple \& Reynolds, 2015; Iovan, et al., 2018; Berndt \& Wirth, 2018). Under their most exacting definitions, pay-for-success is a contract in which government pays a non-government entity to provide a public good only if it meets defined metrics, and social impact bonds are financial instruments through which investors lend to the non-governmental public service provider in exchange for repayment if the PFS contract is successfully delivered (Overholser, 2018). The overall process therefore involves (1) a government entity defining the problem, measure of success, and amount of payment for success, (2) a service provider that contracts with the government to deliver the public service, (3) an outside evaluator to determine if the metrics in the PFS contract are achieved, (4) private investors that lend financial capital to the service provider in exchange for repayment if the PFS contract is met, and (5) intermediaries that help parties to connect with each other and navigate the SIB process (Berndt and Wirth, 2018; Iovan, et al., 2018).

The pay-for-success approach to government services appears to parallel performance-based contracting between firms in the private sector (see Selviaridisa and Wynstrab, 2015). Under these models, the government only pays on the PFS contract if the service is provided along the requested metrics, and furthermore, investors forgive the loan to the service provider rather than seeking to recuperate the capital lent (Overholser, 2018). Social impact bonds appear to have emerged from the UK through the work of Ronald Cohen (Berndt and Wirth, 2018), and many sources describe SIBs as being in their infancy (Berman, 2017; Schinckus, 2017). 
A variety of factors have slowed the spread of SIBs. Interested investors for SIBs face dual risks of the contract not being achieved and the government body not repaying on the contract possibly due to administrative or budgetary changes at the end of these long-term arrangements (Gilbert, 2011). Also, SIBs face criticisms from public sector advocates who see SIBs as another vehicle for private wealth to take over and profit from the vast public sector (Saltman, 2017). However, the main problem with SIBs is that they are expensive, slow, and complex, involving a bureaucracy of intermediaries to maintain a safe political distance between public funds and private investors (Overholser, 2018).

All descriptions in the above sources indicate that the projects funded by SIBs are social service programs that were already being offered by government or non-profit entities. Though the practice of social impact bonds is being imitated by practices such as "development impact bonds" (Clarke, et al., 2019), the practice has not spread its wings to be applied to larger problems.

The approach proposed in this paper goes a step further than current social impact bond practices by not requiring a specific contract or bureaucratic negotiation process between public and private entities (The Mandarin, 2016). Instead, the government would set prices on certain outcomes that serve the public good, allow the private sector to create a market. The next section presents an illustration using arguably the largest and most difficult externality problem facing society.

\section{A PAY-FOR-SUCCESS SOLUTION TO CLIMATE CHANGE}

Climate change presents a problem for which economists are nearly unanimous in support of a Pigouvian tax based on the marginal damage of carbon emissions (Howard \& Sylvan, 2015). However, even sophisticated techniques only produce a range for the marginal cost of each ton of carbon dioxide emitted, which makes it likely that a carbon tax is higher or lower than the optimal tax (Interagency Working Group, 2016). Also, even if the amount of the tax were optimal, it may only motivate carbonemitting activities to move to other jurisdictions, reducing the effectiveness of a tax in any one country on the overall environment (Dinan et al., 2013, p. 17). This imprecision may not matter because carbon taxes are highly unpopular, would slow down the economy, and would fall disproportionately on the most financially insecure members of society (Hsu et al., 2008; Dinan et al., 2013).

However, it appears clear that climate change will result in trillions of dollars in damage by the end of this century (Burke et al., 2018). Based on estimated damage of $\$ 42 /$ ton in 2020 rising to $\$ 69 /$ ton in 2050 , and given that U.S. emission levels hold steady at their current amount of 5 billion tons per year, the cost of U.S. carbon emissions adds up to nearly $\$ 10$ trillion by 2050 (Interagency Working Group, 2016).

As an alternative to taxing U.S. consumers by $\$ 10$ trillion dollars or spending $\$ 2$ trillion on a Green New Deal, the U.S. government could offer anything less than these amounts for a solution to climate change. Given that society appears unlikely to cut emissions (Kagubare, 2018), the federal government could offer $\$ 100$ billion for a process that removes carbon from the atmosphere. This amount is arguably an efficient price for a climate change solution, given the analysis in previous sections.

Fortunately, technology does exist to pull carbon out of the air to be stored or used as fuel (see Minx, et al., 2018; Fuss, et al., 2018; Nemet, et al., 2018). Though scientists in 2011 estimated that pulling a ton of carbon out of the air would cost $\$ 600$ (Socolow et al., 2011), a small company projected the ability to get that number down to between $\$ 94$ and $\$ 232$ in 2018 (Keith et al., 2018). Based on publicly available information, it appears that they achieved this with approximately $\$ 14$ million in investments. This company is Carbon Engineering, and $\$ 14$ million is an estimate based on $\$ 82.4$ million in total investments estimated for the company by crunchbase.com minus the $\$ 68$ million that Carbon Engineering received in investments after making the above-mentioned progress in carbon-capture technology, according to the company's website.

It is important to note that the costs for removing carbon from the atmosphere do not only represent a price for reducing pollution. Carbon that is captured from the atmosphere can be used a fuel, just like carbon mined from fossil fuels. Applied this way, carbon capture technology is emissions-neutral, though

the Second Law of Thermodynamics indicates that there will always be a cost in extracting sources of energy. However, if carbon capture technology becomes cheaper than the social cost of emitting carbon, 
using it will be an efficient use of resources from a cumulative externality perspective. And given the economic costs of a Pigouvian intervention (carbon tax) or government provision (Green New Deal), it would appear that investment in carbon-capture companies would be worth the possibility of paying out a pay-for-success contract on this technology.

Private firms are quietly making headway in carbon-capture technology. Carbon Engineering is a Canadian company that eventually attracted support from Bill Gates (Vidal, 2018). Climeworks is a European company that made significant headway in capturing carbon out of the atmosphere with only several million dollars in funding and has since attracted upwards of $\$ 50$ million in investors (Gertner, 2019). A third company, the Alabama-based Global Thermostat, has also entered the carbon-capture market (Mufson, 2019).

To summarize the above analysis, preventing climate change is arguably worth at least $\$ 10$ billion to the U.S. government, it may be possible to pull carbon dioxide out of the atmosphere at a lower cost than the external marginal damage of emitting it, and worldwide investment into this technology has only been $\$ 116$ million to date (see crunchbase.com analysis of the firms "Carbon Engineering" and "Climeworks"). If these companies produced such promising results with $\$ 116$ million, imagine what they and others could do if the potential payoff were in the billions of dollars. And if billions of dollars for climate change sounds expensive, consider the tens of trillions of dollars that the Green New Deal is estimated to cost (Holtz-Eakin, et al., 2019).

Under this model, the solution to climate change appears to be promising. A market for a variety of innovative technologies could form if the U.S. government promised, for example, $\$ 1$ billion to the first firm that can pull carbon from the atmosphere for $\$ 50 /$ ton at scale, $\$ 5$ billion for the firm that brings that cost down to $\$ 25 /$ ton, and $\$ 10$ billion to bring the cost to $\$ 10 /$ ton.

\section{IMPLICATIONS FOR THE ROLE OF GOVERNMENT}

This paper illustrates how social impact bonds could resolve externalities more efficiently and effectively than Pigouvian taxes and subsidies. But beyond economic analysis of externalities, this proposal also arguably offers an ideal approach to governance.

Public officials may serve their best function by identifying the cumulative cost of externalities and setting prices on the public goods that resolve them. This approach involves debating and deciding on the

agenda for collective action, mobilizing resources around solutions, but then allowing the private market the flexibility and creativity to innovate solutions to these public problems.

\section{REFERENCES}

Acemoglu, D., \& Robinson, J. A. (2001). Inefficient redistribution. American Political Science Review, 95(3), 649-661.

Adler, J. (2011). Eyes on a climate prize: Rewarding energy innovation to achieve climate stabilization. Harvard Environmental Law Review, 35(1), 1-45.

Agiobenebo, T. J. (2006). On the optimal quantity of public goods and related issues. South African Journal of Economics, 74 (2), 294-300.

Baffi, E. (2013). Understanding 'the problem of social cost.' Journal of Advanced Research in Law and Economics, 4(1), 46-52.

Berman, E. (2017). The emergence of social impact bonds. Miller Governmental GAAP Update Service, 17(9), 1-5.

Berndt, C., \& Wirth, M. (2018). Market, metrics, morals: The social impact bond as an emerging social policy instrument. Geoforum, 90, 27-35.

Bretschger, L. (2005). Economics of technological change and the natural environment: How effective are innovations as a remedy for resource scarcity? Ecological Economics, 54(2), 148-163.

Bowen, H. R. (1948). Towards social economy. New York: Rinehart \& Co., Inc. 
Burke, M., Davis, W. M., \& Diffenbaugh, N. S. (2018). Large potential reduction in economic damage under UN mitigation targets. Nature, 557(7706), 549-553.

Caldari, K., \& Masini, F. (2011). Pigouvian versus Marshallian tax: Market failure, public intervention and the problem of externalities. European Journal of the History of Economic Thought, 18(5), 715-732.

Chan, G., Stavins, R., Stowe, R., \& Sweeney, R. (2012). The $\mathrm{SO}_{2}$ allowance-trading system and the Clean Air Act Amendments of 1990: Reflections on 20 years of policy innovation. National Tax Journal, 65(2), 419-452.

Cheng, W., \& Zhang, D. (2006). How should a public good be provided? A transaction cost approach. IDEAS Working Paper Series from RePEc.

Clarke, L., Chalkidou, K., \& Nemzoff, C. (2018). Development impact bonds targeting health outcomes. CGD Policy Paper, 133.

De Geest, G., \& Dari-Mattiacci, G. (2013). The rise of carrots and the decline of sticks. The University of Chicago Law Review, 80(1), 341-393.

Dinan, T. (2013). Effects of a carbon tax on the economy and the environment. Washington, DC: Congress of the United States, Congressional Budget Office.

Fredriksson, P. G. (1998). Environmental policy choice: Pollution abatement subsidies. Resource and Energy Economics, 20(1), 51-63.

Fu, Q., Lu, J., \& Lu, Y. (2012). Incentivizing R\&D: Prize or subsidies? International Journal of Industrial Organization, 30(1), 67-79.

Fuss, S., \& Minx, J. C., et al. (2018). Negative emissions - part 2: Costs, potentials and side effects. Environmental Research Letters, 13(6), 1-47.

Gertner, J. (2019). The tiny Swiss company that thinks it can help stop climate change. The New York Times, February.

Gilbert, K. (2011). The appeal of the social impact bond. Institutional Investor, June.

Gruber, J. (2016). Public finance and public policy (5th ed.). New York: Worth Publishers.

Heres, D., Kallbekken, S., \& Galarraga, I. (2017). The role of budgetary information in the preference for externality-correcting subsidies over taxes: A lab experiment on public support. Environmental and Resource Economics, 66(1), 1-15.

Holtz-Eakin, D., Bosch, D., Gitis, B., Goldbeck, D., \& Rossetti, P. (2019). The Green New Deal: Scope, scale, and implications. The American Action Forum. Retrieved from https://www.americanactionforum.org/research/the-green-new-deal-scope-scale-andimplications/\#_edn9

Howard P., \& Sylvan, D. (2015, December). Expert consensus on the economics of climate change. New York: Institute for Policy Integrity.

Hsu, S.-L., Walters, J., \& Purgas, A. (2008). Pollution tax heuristics: An empirical study of willingness to pay higher gasoline taxes. Energy Policy, 36(9), 3612-3619.

Interagency Working Group on Social Cost of Greenhouse Gases. (2016). Technical update of the social cost of carbon for regulatory impact analysis under Executive Order 12866. Washington DC: United States Government.

Iovan, S., Lantz, P. M., \& Shapiro, S. (2018). 'Pay for success' projects: Financing interventions that address social determinants of health in 20 countries. American Journal of Public Health, 108(11), 1473-1477.

Johnson, D. M. (1995). The economics of stock pollutants: A graphical exposition. The Journal of Economic Education, 26(3), 236-244.

Kagubare, I. (2018). Nations are not reducing emissions quickly enough to meet $2 \mathrm{C}$ target. Scientific American, November.

Keith, D. W., Holmes, G., St. Angelo, D., \& Heidel, K. (2018). A process for capturing $\mathrm{CO}_{2}$ from the atmosphere. Joule, 2(8), 1573-1594.

Madjd-Sadjadi, Z. (2016). The economics of civil and common law. New York: Business Expert Press. 
Masur, J. S., \& Posner, E. A. (2015). Toward a Pigouvian state. University of Pennsylvania Law Review, 164(1), 93-122.

Metcalf, G. E. (2009). Tax policies for low-carbon technologies. National Tax Journal, 62(3), 519-533.

Miller, N. (2006). Chapter 8: Externalities and public goods, in Notes on Microeconomic Theory.

Retrieved from https://www.business.illinois.edu/nmiller/documents/notes/notes8.pdf

Minx, J., \& Dominguez, M. D. Z., et al. (2018). Negative emissions - part 1: Research landscape and synthesis. Environmental Research Letters, 13(6), 1-29.

Mufson, S. (2019). A climate change solution slowly gains ground. The Washington Post, April.

Musgrave, R. (1957). A multiple theory of budget determination. Finanzarchiv, 17(3), 333-343.

Nault, B. R. (1996). Equivalence of taxes and subsidies in the control of production externalities. Management Science, 42(3), 307-320.

Nemet, G. F., \& Smith, P., et al. (2018). Negative emissions - part 3: Innovation and upscaling. Environmental Research Letters, 13(6), 1-30.

Orchard-Webb, J., Kenter, J. O., Bryce, R., \& Church, A. (2016). Deliberative democratic monetary valuation to implement the ecosystem approach. Ecosystem Services, 21, 308-318.

Ostrom, E. (2012). Nested externalities and polycentric institutions: Must we wait for global solutions to climate change before taking actions at other scales? Economic Theory, 49(2), 353-369.

Overholser, G. M. (2018). Pay for success is quietly undergoing a radical simplification. ANNALS of the American Academy of Political and Social Science, 678(1), 103-110.

Pass, C. L., Lowes, B., \& Davies, L. (2005). Collins dictionary of economics (4th ed.). New York: Collins.

Paton, J., \& Bryant, G. (2012). Valuing pollution: Problems of price in the commodification of nature. The Economic and Labour Relations Review, 23(1), 87-106.

Rangan, V., \& Chase, L. (2015). The payoff of pay-for-success. Stanford Social Innovation Review, 13(4), 28-39.

Richardson, J., Iezzi, A., Sinha, K., Khan, M. A., \& McKie, J. (2014). An instrument for measuring the social willingness to pay for health state improvement. Health Economics, 23(7), 792-805.

Saltman, K. J. (2017). The promise and realities of pay for success/social impact bonds. Education Policy Analysis Archives, 25(59), 1-17.

Selviaridisa, K., \& Wynstrab, F. (2014). Performance-based contracting: A literature review and future research directions. International Journal of Production Research, 53(12), 3505-3540.

Schinckus, C. (2017). Financial innovation as a potential force for a positive social change: The challenging future of social impact bonds. Research in International Business and Finance, 39, 727-736.

Schlag, P. (1989). The problem of transaction costs. Southern California Law Review, 62, 1661-1805.

Social bond collapse blamed on 'tedious bureaucratic processes.' (2016). The Mandarin. Retrieved July 29, 2019, from available at https://www.themandarin.com.au/67636-new-zealandfirst-socialimpact-bond-collapses/

Socolow, R., \& Wilcox, J., et al. (2011). Direct air capture of $\mathrm{CO}_{2}$ with chemicals: A technology assessment for the APS Panel on Public Affairs. American Physical Society.

Spash, C. (2007). Deliberative monetary valuation (DMV): Issues in combining economic and political processes to value environmental change. Ecological Economics, 63(4), 690-699.

Steinacker, A. (2006). Externalities, prospect theory, and social construction: When will government act, what will government do? Social Science Quarterly, 87(3), 459-476.

Sterner, T. (2002). Policy instruments for environmental and natural resource management (1sted.). New York: Routledge.

Temple, J., \& Reynolds, A. (2015). Using benefit-cost analysis to scale up early childhood programs through pay-for-success financing. Journal of Cost-Benefit Analysis, 6(3), 628-653.

Tideman, N. T., \& Plassmann, F. (2010). Pricing externalities. European Journal of Political Economy, 26(2), 176-184.

VanDoren, P. (1989). Should Congress listen to economists? The Journal of Politics, 51(2), 319-336. 
Vidal, J. (2018). How Bill Gates aims to clean up the planet. The Guardian, February.

Williams, M., Swenson, C. W., \& Lease, T. L. (2001). Effects of unitary vs. nonunitary state income taxes on interstate resource allocation: Some analytical and simulation results. Journal of the American Taxation Association, 23(1), 39-60.

Wilson, J. Q., \& Dilulio Jr., J. J. (1995). American government: institutions and policies. Lexington: D.C. Health. 